\title{
THE SOCIAL CONSTRUCTION OF CONTEXTUAL RATIONALITIES IN MNCS: AN ANGLO-GERMAN COMPARISON OF SUBSIDIARY CHOICE**
}

\author{
MIKE GEPPERT \\ KAREN WILLIAMS \\ University of Wales Swansea \\ DIRK MATTEN \\ University of Nottingham
}

To be published in 2003 in the Journal of Management Studies, 40/3: 613-637.

\section{ABSTRACT}

This paper seeks to examine empirically the extent to which actors in subsidiaries of multinational companies (MNCs) are able to exercise some choice in the face of global pressures from the MNC headquarters (HQ). We argue that managerial practices in MNCs are not the result of a simple imposition of a global or a MNC organisational rationality but are subject to an interactive process, where differing contextual rationalities come into play. Using data from MNC subsidiaries in Britain and Germany, the paper compares the power resources and strategic choices of subsidiary level actors and shows the ways in which they seek to influence global strategy implementation as it affects local work systems. We investigate the different abilities of German and British managers to shape global restructuring processes in their local organisational contexts and conclude that national contexts impact on both the formulation of parent company strategies via a home country rationality and on the implementation of global strategies via a host country rationality. There are greater national barriers to a MNC policy of convergence based on standardized products and processes in Germany than in the UK.

\section{INTRODUCTION}

Our study compares the scope for strategic choice in managerial practices in the British and German subsidiaries of three MNCs in the Lifts \& Escalators industry. Whilst recognising the powerful influence of global rationalities, of which many examples can be found in our empirical data, national business systems (NBSs) also play a very important part in the construction of the rationalities of both HQ and local actors within the MNCs. The focus of our paper is on the social construction of these contextual rationalities at subsidiary level.

Contrary to approaches that stress the increasing convergence of organisational rationalities in the international business context, (cf. Ohmae, 1990 and Mueller, 1994), our ideas on HQsubsidiary relations are based on a less deterministic concept of organisational-environmental linkages. Organisational behaviour can never be perfectly determined by external global effects (Weick, 1979, pp.130-132) and local actors have varying scope for managerial choice. In contrast to many studies of MNCs, we investigate not only the globalization strategies as outlined by HQ managers but also the ways in which these strategies have been applied in practice. This reveals the different choices and constraints which actors face in the actual implementation process at subsidiary level.

Based on a more general discussion about strategic choices and resource dependencies of national subsidiaries, we seek to identify some of the opportunities and constraints shaping 
strategic choice at the subsidiary level. These are dependent on the power resources of the different actors, which, we argue, are influenced by global, MNC home country and subsidiary host country rationalities.

\section{UNDERSTANDING MANAGERIAL PRACTICES AND SUBSIDIARY CHOICE IN MNCS}

Many studies on globalisation continue the earlier debate about the impact of industrialisation on organisational convergence (Pugh and Hickson, 1997), arguing that technological, economic, political and cultural sources are the driving forces of globalisation (Parker, 1998) and are leading to the stateless or global firm (Ohmae, 1990, p.94). It is assumed that national, cultural and institutional differences have lost their significance. In a similar vein, Whittington and Mayer (2000) argue that the structures and business practice of global firms will inevitably follow the Anglo-Saxon model of capitalism with the decline of national financial systems and the increasing influence of shareholder-value. Global companies are seen as using similar tools, such as downsizing, to reach market based performance goals (Hirsch-Kreinsen, 1998, Hunt, 2000) and finance driven changes involved in the process of globalisation are said to lead to a convergence of management styles (Hunt, 2000). Thus, 'organisational effects' or global organisational rationalities are understood as global management patterns, which are emerging through learning across borders and the internationalisation of 'best practices' (Mueller, 1994). Such arguments conclude that these changes are weakening the effect of national societal institutions on business and reducing the scope for strategic choices of MNC subsidiaries.

However, other empirical studies draw a rather different picture by emphasising the home embeddedness of MNCs and the impact of host country NBSs on MNC-subsidiary relations. A recent study of Child et al. (2001), for example, compares the influence of the NBS on the management of international acquisitions. The authors analyse trends in post-acquisition management in US, UK, Japanese, German and French companies and show significant home country effects on integration and control mechanisms, HRM practices and the process of post-acquisition changes in the acquired companies. Moreover, research about employment practices in German and US MNCs shows the continuing influence of the home country business system pattern. Edwards and Ferner (2001) illustrate how the nature of the American finance system leads to short-term financial pressure in US MNCs and with it to the erosion of job security and an increasing division between core and temporary workers in these companies. Ferner and Varul's study about the diffusion of new practices in German MNCs shows that home country effects are still relevant to understanding the internationalisation of these firms and conclude that international borrowings may not necessarily erode national differences, since elements of practice acquire a different meaning when located in a different business context' (2000, p.137). Wever similarly points to the need for 'adaptive learning' by US and German MNCs based on an understanding of their organisations in both their domestic and international contexts (Wever, 1995, pp.209,222).

Recent studies about the management of multinational subsidiaries also show how host country subsidiaries can be relatively autonomous units influenced by the local business environment and are thus sources of local variation in the globalisation process (e.g. Belanger et al., 1999). They are able to develop a more active role within the management process of MNCs (e.g. Birkinshaw, 2000) as illustrated by the recent debate about 'multinational subsidiary evolution' (Birkinshaw and Hood, 1998), 'subsidiary initiatives' (Birkinshaw and Fry, 1998) and 'entrepreneurship in the global firm' (Birkinshaw, 2000), which focuses on 
the idea of subsidiary choice and the change or maintenance of subsidiary 'charters' 'in terms of markets served, products manufactured, technologies held, functional areas covered or any combination thereof' (Birkinshaw, 2000, p.86). This research stream emphasises primarily the optimal fit of subsidiary structures and processes with particular 'local environmental determinants', but also take into account social and communication type issues such as the structuring of negotiations over charters etc. However, in Birkinshaw's account, these issues are not understood as being socially embedded.

More recently, other authors have linked these processes to the power of different actors in particular contexts, which derive from their location in distinctive NBSs. For example, Kristensen and Zeitlin (2001) have shown how, within one multinational firm, different subsidiaries have distinctive powers to influence HQ decisions because of the distinctive pattern of skills and competences which exist within them. These patterns derive from their positioning within a particular NBS. This suggests the importance of linking the idea of subsidiary choice to the broader area of literature concerned with NBSs. The following paper examines these issues through an empirical analysis of three MNCs from distinctive business systems (the USA, Germany and Finland) and their subsidiaries in Germany and the UK. In particular, we analyse the social construction of contextual rationalities through our comparison of subsidiaries in the UK and Germany.

\section{RESEARCH DESIGN AND METHODOLOGY}

This paper forms part of a wider research project to analyse change management processes in MNCs, which has been jointly developed with researchers from Germany. Elsewhere the focus has been on the (top-down) application of new strategies by power holders at MNC HQ level (Becker-Ritterspach et al., 2003). This paper considers the strategies from the subsidiary level perspective and investigates the emerging choices and constraints in the management practices of local managers in German and British subsidiaries of three MNCs in the same industrial sector as they interact with their wider social context within the host country and within the MNC itself. The MNCs, in turn, are influenced both by their country of origin as well as wider globalization pressures. The different interactions will lead to different rules, different institutions, different controls and different critical contingencies (Weick, 1979).

\section{insert Table 1 about here}

To analyse these issues we selected three of the four major global players of a relatively small business sector, Lifts \& Escalators (for details see Table 1). All have HQs in different host countries; Amy in the USA, Jukka in Finland and Karl-Heinz in Germany. All three companies have national subsidiaries in Germany and in the UK. We expect the managerial choice and practices of the subsidiaries to be influenced by their social embeddedness in quite distinct national systems in Germany and the UK (Lane, 1992); with the German context, in particular, promoting the continuation of the manufacturing focus which is fairly strong in both companies. 


\section{insert Table 2 about here}

Qualitative research methods were used in the form of interview guidelines and semistructured questionnaires in German and English for managers involved in or responsible for change management measures in their companies. In-depth expert interviews were conducted between spring 2000 and summer 2001 with MDs and managers at the MNC level (in the HQ and its functional subunits) and at subsidiary level in both countries. Moreover, works councillors and union representatives of the Lifts \& Escalators industry were interviewed in both countries. Table 2 gives on overview over the interviews conducted in our co-operation with our German partners. In the interviews we sought general information about the company, past, present and planned reorganisation and change processes, details on the starting points of change and managers' assessment of the positive and negative aspects of the subsidiary's location in a particular national context as well as the influence of the MNC's country of origin. Additionally, official documents of these companies, newspaper and internet sources were included.

\section{COMPARATIVE DISCUSSION OF THE EMPIRICAL FINDINGS}

In the following section, we reveal the competing rationalities at work within the companies at the HQ and subsidiary levels and show how these relate to issues of national embeddedness. Firstly, we investigate the concept of a universalised economic rationality in the globalisation strategies of the MNCs in the lift and escalator industry, which are designed to enable the companies to better meet the demands of a global market. Secondly we show that these strategies do in fact reflect the impact of home country rationalities on the MNCs. Thirdly, we look at the host country contextual rationalities of the subsidiaries themselves. This reveals that the goals set by the HQ for the subsidiaries have to go through the prism of the different business contexts of Germany and the UK. The result is that in Germany there is considerable resistance to certain types of HQ strategies whilst these same strategies are smoothly implemented in the UK subsidiaries.

\section{Global Rationalities}

Throughout the Lifts \& Escalators industry worldwide, similar global organisational rationalities are visible in strategies to move to more customer services operations in the West and to shift production sites into Eastern Europe or China. As technology, product quality and costs become similar, the area of competitive advantage is seen as customer service operations and the service sector in all the major companies is undergoing rationalisation and restructuring. Service, fitting and marketing are becoming increasingly important for enterprises in this industrial sector, because these functions add higher value than manufacturing and, thus, appear to be more attractive in the drive for short-term profits (Iwer, 2000, pp.31-32). There is also a shift towards centralization of strategic decisionmaking and increasing standardization of business practices as standardized products and services are developed with the global market in mind. All the key companies in the sector are also involved in acquisitions to extend their market reach (ibid, p.12). There is also evidence of a shift towards the 'Anglo-Saxon model' of business with an increased emphasis 
on 'shareholder value' (ibid, p.9) and standardised financial reporting to meet the requirements of the US capital markets (Becker-Ritterspach et al., 2003).

In terms of the standardization of business practices in our three MNCs, our research partners' work points to an increase in indirect methods of coordination and control in all three MNCs, including the use of financial indicators to measure performance, radical sanctions if subsidiaries fail to perform well and share options for top management at all levels to lock them into the shareholder value perspective (Becker-Ritterspach et al., 2003). Amy showed the greatest level of acceptance and operationalization of the shareholder value concept through individual company performance targets expressed in earnings per share and constant reference by all managers interviewed to shareholder value as the driving force behind company policies and practices. Jukka has been developing a more finance driven system since it began its internationalisation programme in the late 1960s. Although it is family owned and therefore not directly subject to shareholder pressures, there is evidence of it benchmarking its operations against the priorities of international investors, a marked trend in the Finnish economy generally according to Tainio et al. (2001, p.153). This sort of 'normative isomorphism' (DiMaggio and Powell, 1991) in the Finnish business system is reinforced by an increasingly finance orientated global manufacturing discourse, as a recent study of language within the lifts and escalators sector indicates (Geppert, 2002). An indicator of this overall trend is, for example, the introduction of the US GAAP system of financial reporting for all subsidiaries in Karl-Heinz, the creation of independent profit centres in its German production plants and a system of performance related pay based on the company's share price for all executive staff point to softer financial controls. Lane describes this as 'a diluted concept of shareholder value' (Lane, 2001, p.88), which reflects the slow progress of Germany towards a shareholder value economy in contrast to other European countries (Jurgens et al., 2000). Schmidt and Williams (2003) found shareholder value being used as an important management tool only in the new knowledge based industries in Germany, whilst Ferner, Quintanilla and Varul (2000, p.111) show that the adoption and implementation of shareholder value, among other Anglo-Saxon practices, is taking place 'in a distinctively German way'.

Other standard business practices found included the development of a global manufacturing strategy in terms of creating a standardised product for the global market in the two MNCs, who had either internationalised already or were on that road - Amy and Jukka. This involved in Amy a reduction and shift in manufacturing sites (all UK manufacturing was ended) and the move towards standardised products and the standardised work systems to produce them. Karl-Heinz, in contrast, continued the focus on more customised production models, which hindered the development of a global manufacturing strategy.

\section{Home Country Rationalities}

Although we found evidence of certain 'globalizing effects' in the MNCs, there were considerable differences in the globalisation strategies adopted and in the speed and extent to which such strategies were being implemented by the market leader companies. Explanations for these differences can be found in the importance of the home national culture and institutions (see, for example, Doremus et al., 1998). The literature on the importance of the country of origin effect on MNCs builds on NBSs studies (see Whitley, 1992, Whitley and Kristensen, 1996, Lane, 1989). Child et al's recent study on the management of international acquisitions underlines the continuing importance of the national origin of the acquiring company and the direct application of home country practices to subsidiaries, particularly in MNCs from 'dominant' business cultures such as the US (2001, p.46). We use 'dominant' to 
reflect the ability of actors to 'shape the transnational space directly' by virtue of their economic, military and geopolitical resources as well as ideological supports (see Djelic/Quack, 2002 p.12, 20). Even MNCs from less dominant systems, such as Germany, demonstrate the subtle exertion of a country of origin effect on their subsidiaries and globalize in a way, which is distinctive and supportive of their home country rationalities (Ferner et al., 2000, p.123 and 111).

Our study found clear differences in the type and variety of performance indicators and the ways in which they were used by the three MNCs and the extent of control exercised over the subsidiaries also varied. These have been linked to the very different ownership structures of the MNCs and the different globalization strategies adopted (Becker-Ritterspach et al. 2003), which, we argue, are influenced by home country rationalities of the three MNCs. The centralization of the US MNC in the process of developing a global manufacturing strategy is leading to the new focus on tighter operational control of its subsidiaries. This new type of control runs alongside existing financial controls and re-emphasizes the centrality of the US HQ in all decision making. Home country rationalities, however, are not simply static parameters, but might undergo some quite significant changes and transitions, as the further discussion of the Finnish case will surface.

US Home Country Effect. The US MNC in our study, Amy, is part of a very large US conglomerate (29 Billion US-\$ revenue in 2001), which does most of its business in the US. It was the first of the three MNCs to internationalize via a process of mergers and acquisitions, which began in the 1950s and has developed a global manufacturing strategy, in which the level of autonomy of its subsidiaries varies considerably. Control is exercised mainly through tight performance targets. Amy is currently pursuing the rationalisation and restructuring of the business activities of the whole $\mathrm{MNC}$ much more radically than the other two companies investigated. The strong influence of the American parent company is significant here as it seeks to cut 14,500 jobs world wide by introducing shared services and purchasing arrangements; a trend, which has been particularly marked since the international restructuring in 1999. An important part of Amy's corporate strategy is the continuous rationalisation of their operations by assessing, for example, which of their global manufacturing tasks can be outsourced or bought externally to reduce fixed costs and utilise international differences in labour costs (Iwer, 2000). A concentration process is currently underway with a cut in its production plants from 39 to 16 and its research and development sites from 16 to 6 . The threats from the point of view of the German subsidiary are a further concentration of R\&D functions in the USA ('retrenching process') and the shift in standardized production to lower labour cost countries such as the transfer of production of the so-called 'supermarket escalators' from Germany to the Czech Republic (ibid, p.29).

The US NBS facilitates a 'unilateral approach', where the focus is on the individual companies to develop their own organizational models, largely in isolation, due to the lack of collaborative institutional and business structures (Wever, 1995). Strategy in US companies is largely driven by the stockmarket due to ownership relations based on external stockholdings. This leads to short term strategies oriented towards increasing shareholder value, which are intensifying with the increase in global competition. Strategy is centralised and manifests itself in a strong drive for efficiency with control exercised by formalised systems of analysis and planning and a high level of integration between the HQ and its subsidiaries. Targets, reward systems are all geared towards short term financial goals (Child et al., 2001, p.52). Alongside the traditional output controls associated with US MNCs, there has been an increase in the use of input controls and studies of US MNCs operating in a variety of different fields underline other distinctive US features such as the centralised control of all areas of operation and the sidelining of host country NBS influences in the drive to meet the needs of the MNC and global economic pressures (cf. Royle, 1995). Similar to these findings, Amy has recently introduced higher levels of input control as part of their centralizing strategy to create a global product. Child et al. (2001, p.82) similarly find post 
acquisition management by US MNCs to be 'hands on, forceful and distinctive'. The US subsidiaries they investigated were subjected to the highest level of absorption but were also given high levels of support (ibid, pp.147-148).

Amy reflects many of the typical properties of an US-American MNC in its forceful American management style, the management bias towards accountancy, financial management and budget control and negative attitudes towards worker representation. The Director of Human Resource Programmes in the German subsidiary gave the following as an example of the US orientation:

'We manage, as we always have, with performance indicators - that is part of American culture... What's changed is the centralization of certain areas and we've strengthened the role of the HQ so that the autonomy of national subsidiaries to do what they want to do as long as they achieve their profit targets has been reduced.'

Other management respondents argued that change was constant as was the pressure to meet stock market requirements via individual company performance targets being expressed in earnings per share. Power was being concentrated at HQ level and increasing insensitivity to national differences in the subsidiaries was evident. This was demonstrated, for example, in the HQ allocation of the UK subsidiary to the Southern European group, which was viewed as nonsensical by subsidiary management. The closure of the Paris based European HQ in the 1990s was seen by German subsidiary management as another effort to reduce European influence on the MNC and concentrate power resources in the US. Amy is seeking a standardisation and convergence of manufacturing operations in its bid to be a cost leader in standard lifts and escalators (Matten and Geppert, 2002). This reflects the market driven orientation of US companies rather than R\&D orientation (Child et al., 2001, p.82). Amy's German subsidiary has seen a shift from the previous policy of a reasonably high level of autonomy in the subsidiary to reduced autonomy in the finance driven relocation of manufacturing to Eastern Europe and China. So far, the subsidiary goes against the US trend to absorb acquisitions and integrate them tightly into the MNC operations but recent strategy changes indicate that this may become a more marked feature in the future. In the wake of Amy's global manufacturing strategy, German subsidiary management have sought to negotiate with the US HQ to retain the high value added products in Germany to safeguard jobs and wage levels of employees. Future contestation is likely as Amy increasingly outsources to Eastern Europe. However, as long as the outsourcing focuses on the lower value added standardized products, as it currently does, the contestation will be muted.

Finnish Home Country Effect. Jukka is a family owned, specialist lift company and was the first major Finnish company to adopt a policy of international acquisitions in the late 1960s. Its German subsidiary was acquired in the 1990s to add escalators to Jukka's portfolio and the British subsidiary previously belonged to the acquired German company and still has strong ties to it. Jukka is pursuing a global integration strategy, which includes a high level of centralised coordination of its subsidiaries.

Studies of the Finnish NBS highlight the traditional characteristics of corporate specialisation linked to the forestry industry. The industry evolved into a hi-tech, science based industry and has spawned other hi-tech sectors, such as the Finnish electronics industry (Lemola et al., 1988, p.140; Marceau, 1994, p.166). The national production and innovation system, supported by patient bank and state capital, is seen as a factor in explaining current areas of Finnish specialisation and a specific Finnish way of internationalizing associated with the 
tight coupling of inter-firm relations and a specific sectoral knowledge base (Lemola et al., 1988, p.149-150; Lilja and Tainio, 1996, p.186). Lilja and Tainio (1996) investigate the traditional collaborative type of business system in Finland and point to factors creating pressures for change. They argue that the 'typical' Finnish company now sees the greater focussing of its business operations and the drive towards a higher position in European and global markets as top priorities (ibid, p.185). Government promotion of the globalization of Finnish companies and the opening up of the Finnish economy to foreign capital is putting pressure on the old collaborative hierarchies (Marceau, 1994, p.171; Kristensen et al., 1996, p.115,117) and are leading to some changes in the NBS. There have been a significant international drive and aggressive acquisition policies of the largest Finnish companies to build up their market power in the 1990s (Moen and Lilja, 2001, pp.98-99). Government policies have also changed to allow unrestricted foreign ownership of Finnish companies, whilst the banks have ended their controlling ownership stakes in the companies. The recent increase in the importance of international investors has led to a more finance driven management culture and shareholder value has become part of the Finnish management rhetoric (ibid, pp.113-117). Tainio (2001, pp.169-170) points to the increasing Americanisation of Finnish companies and the growing dominance of shareholder value, even in companies where there is as yet no foreign ownership.

This is reflected in our case study company, which although family owned is increasingly finance driven in its strategies and operation. Jukka has imposed a standardised ' $J u k k a$ model' on all its international subsidiaries. This abolishes the concept of national entities and orientates operations towards the international market by a clear separation of the different functions: 'Supply line' (manufacturing and R\&D) and 'Front line' (sales and services). These involve the same manufacturing processes, technological organisation and strategies regardless of the national background of the subsidiaries and their administrative heritage. This has led to high levels of friction with their national subsidiaries, particularly in Germany. Although the Finnish business system is characterised by the drive for technological excellence and innovation (Lilja et al., 1992) and Jukka reflects this with leading edge products in the lifts sector, the Finnish system focuses on the rapid application of breakthroughs in basic technology to selected fields (Lemola and Lovio, 1988, p.152). Jukka demonstrates this in the exploitation of a competitive advantage in its standardised global elevator product in order to achieve quality leadership in the mass market. This requires economies of scale and scope in integrated production sites, which conflicts with the German focus on high level customised production. A further area of conflict can be seen in the fact that the new finance driven culture in Finnish companies makes it easier for management to turn down engineers' ideas for investments and concentrate on the priorities of international investors (Moen and Lilja, 2001, pp.117-118).

Jukka has in recent years attempted to impose its standardisation strategy on the German subsidiary, the last subsidiary to be integrated into the Jukka model. This has put enormous pressure on the earlier high level of autonomy of the subsidiary:

'We have bought very independent companies, they were doing their strategic choices in the companies as well, in their own countries but now definitely, the head office has really taken, let's say, the strategic leadership in the company ...the national companies, the country units, their role is much more how to implement those strategies.' (Director of Management Development, Jukka, Helsinki)

The struggle of local management in Germany to maintain control of the company has been intense and is still ongoing. The implementation of the Jukka-model is leading to Finnish HQ 
attempts to rationalise operations and the subsequent reorganisation is seen as a threat by German staff since the Finnish HQ ethos is: 'if we are able to do things more effectively, less people are required'. The mistrust generated has led to communication problems between the Finnish managers and the German workforce. The conflict is an example of 'non-negotiated attempts at imposition of systems', which often end in frustration (Ferner, 2000, p.529) and represents a power struggle in which the German subsidiary has been drawing on resources from the German business system as well as from its strategic position within the MNC itself to promote a different rationality to that of the parent company. Initially the aim is to legitimate the continuation of its own actions; if this is successful, however, it could seek to influence the broader strategic direction of the company as a whole in its role as leading $\mathrm{R} \&$ $\mathrm{D}$ centre. The parent company has enforced its direct personal authority via the importation of Finnish managers from the HQ to enforce the Jukka-policy, however, only after the longstanding German managing director retired. They still face a long battle to impose the social norms to support Jukka's formal control mechanisms in a business system hostile to its goals. They also have to tread carefully due to the strategic importance of the German subsidiary's R\&D and technical competences for the $\mathrm{MNC}$ as a whole. The traditional Finnish collaborative approach is reflected in Jukka in the use of workshops involving all the key companies in the MNC to aid in the formulation of strategy. However, once the strategy has 'emerged', no further discussion is tolerated and it is implemented across all subsidiaries with limited reference to national peculiarities. The manager leading the task force responsible for the implementation of the Jukka-model worldwide referred to the high emphasis on financial control in strategic management decisions but sees the need for Jukka HQ 'to take the foot of the pedal a little bit in that area and try to be more supportive rather than supervisory in that respect...'. The risk associated with this process is the possible loss of home country advantages over time as technological excellence and collaborative structures are undermined by a new finance-driven management culture. There is also a risk of losing host country advantages in the subsidiaries as shown in the German subsidiary's struggle with the MNC's new global strategies.

German Home Country Effect. Karl-Heinz is part of a German conglomerate with a traditional focus on heavy engineering. German banks and foundations have large shareholdings in the conglomerate (about 40\%) and Karl-Heinz is not quoted on the stock market. It has recently embarked on a cautious internationalisation process but is following a 'local responsiveness' strategy of local differentiation among its foreign subsidiaries. Lane's recent work (2001) on German TNCs points to an increase in centralized integration strategies and greater Anglo-Saxonization of German MNCs but our own and other studies outlined below show that German companies are 'a mixed bag'. The German business system is described by Wever (1995) as adopting a 'negotiated approach' in contrast to the US unilateral approach. It shows a marked departure from the neo-classical free market model and operates on the basis of institutional and organizational linkages, which promote the negotiation of adjustment issues between the major stakeholders, including the employees (Wever, 1995, pp.11-14). Ferner, Quintinalla and Varul (2000, p.109) describe some of the key characteristics of the German system as a long termist focus, family ownership, late internationalisation, highly developed vocational, education and training systems with a high skill labour force, consensus and cooperative relations between management and labour. All these characteristics are reflected in our case study MNC, which can be seen as a 'typical German company'.

The current debate about the German NBS focuses on whether German MNCs are shifting towards a more Anglo-Saxon orientation in business and what will be the effects on the 
German system. Studies of German employer attitudes indicate their general support for what they see as the strengths of the German model, including high skills, cooperative relations and stability (Wever, 1995, p.16; Girndt and Meiners, 2002; Schmidt and Williams, 2003, for example). Ferner and Varul (2000, p.137) further point out that German model companies are very successful internationally, which is also true of our German MNC in the lifts and elevator industry.

Karl-Heinz has major manufacturing locations worldwide, focusing on Diversified Quality Production (DQP) technology in its German subsidiaries whilst the more standard components manufacture is on constant pressure from potential Eastern Europe locations (Girndt and Meiners, 2002). There is close functional integration between R\&D, sales and service and manufacturing with a cross fertilization of ideas between the three areas. Some of the distinctive German influences as seen by management were the strong manufacturing and engineering culture and the works council system of worker representation, aspects of which had been transferred to its UK subsidiaries. HQ management representatives in Germany emphasized the relative autonomy of subsidiaries to run their own operations:

'Fundamentally, we have always followed a very decentralized philosophy and believe that our subsidiaries are in a better position to know their own markets and how best to sell their products on the market and their services; that they can do that most successfully. There are only a few specific areas like the uniform reporting system, some $\mathrm{R} \& \mathrm{D}$, which we need to centralize; in everything else our subsidiaries are relatively free if they perform well. If they don't, then we have to step in but basically they should have the freedom to develop their business in a sensible way.'

This perspective is supported by our data from the German manufacturing subsidiary. Innovations have been introduced including the recent introduction of lean production into lift manufacturing. This was seen as a painful process as it led to the abolition of traditional organisational hierarchies on the shop floor and their replacement with group working. Incidentally, it was successfully achieved via negotiation with the stakeholders in the local organisation. Although the changes have led to some reduction in the autonomy of the shop floor, the process has been far less conflictual than in the German subsidiary of Jukka.

The high level of decentralization in Karl-Heinz can well be understood as a general feature of the German system. A recent study by Lane (2000) shows German MNCs allocating more resources and competencies as well as organizational and financial autonomy to their subsidiaries to develop networks in host countries similar to those existing in German industry. In addition, Child et al. (2001, pp.225,233) have highlighted German MNCs as the least effective MNCs in terms of their direction over the policy of their acquisitions and the level of integration of their subsidiaries. This partly reflects their lower level of experience in managing international subsidiaries and also their wish to preserve and learn from the competences of their subsidiaries. Ebster-Grosz and Pugh's (1996) study of the relations between British subsidiaries and their German parent companies also highlights the inherent 'German-ness' of the parent companies, berated by the subsidiaries for their domestic rather than international orientation and poor strategic management seen as linked to consensus decision making. The 'virtues' of the German business environment were seen as vices by subsidiaries operating in a more liberal, fast changing business environment in the UK. This point is taken up again in the next section of the paper.

\section{Host Country Rationalities.}


Our outline of home country rationalities underlines their continuing importance in shaping the globalization strategies of MNCs in general and in the lifts and escalator industry in particular. The different strategies, which emerge, have important implications for the scope of subsidiary choice.

In this section of the paper we investigate the effect of host country rationalities on the power resources of subsidiaries and their consequent ability to shape their own agenda in the relationship with the parent company. Ferner (2000, p.529) argues that national institutional and business environments provide both added leverage for subsidiary resistance to the MNC HQ and power resources in the operating units themselves. The performance of the subsidiaries and their strategic importance to the MNC are also key factors (Ferner, 2000, p532), which, we argue, can be traced back to the national business environment. The fact that MNCs have to rely on their national subsidiaries to interpret the local environment for them (Ferner, 2000, p.530), albeit to different extents depending on the globalization strategy pursued, gives local management a strong position in their relationship with the MNC HQ. Although the HQ can challenge their interpretation and, as we see in one of our case studies, seek to overturn it, this is a risky strategy, which can lead to high levels of conflict, the loss of credibility of local management and of the NBS advantages the MNC is seeking to exploit in setting up the subsidiary in the first place.

British host country rationalities. The British NBS can be seen as the polar opposite of the German system. Ebster-Grosz and Pugh describe it as 'liberal' with low stability of industrial activity due to short-term management open to stock market pressures. The manufacturing infrastructure is in decline and is less well defined than in Germany with low levels of investment and low status. The focus is on market mechanisms for coordinating the supply and provision of key resources such as labour, capital and supplies. There is a low level of linkage between industry and other institutions such as the education system, unlike the German collaborative structure. The industrial environment is generally far less predictable than the German one (Ebster-Grosz and Pugh, 1996, pp.31-33; Hall and Soskice, 2001; Vitols, 2001; Wood, 2001). British strengths are seen as residing in financial entrepreneurship and in the finance industry as well as the fast moving sectors such as IT and consumer electronics rather than in traditional industrial development (Ebster-Grosz and Pugh, 1996, p.34). Ferner and Varul (2000, pp.121-122) argue that the UK can be seen as a site of vanguard practices for German MNCs due to its integration in the international economy, openness to foreign direct investment (FDI) and weak regulative framework, particularly for industrial relations. This creates the conditions for leading edge practices to emerge. Reverse diffusion of practices from the UK to Germany is, however, limited due to the German NBS, where there is resistance both from HQ administrative staff, who are oriented to national organization of the MNC and at local level with works councils ready to challenge any changes to the high skill, high cost labour practice model (ibid, pp.134-135). To further highlight the British system characteristics, in Ebster-Grosz and Pugh's study, criticism of British parents by German subsidiaries centred on neglect by the parent, individualistic decision making with constant modifications to decisions, poor operational organization and an inability to see themselves as part of Europe (Ebster-Grosz and Pugh, 1996, p.193).

Our research underlines the high level of compartmentalization of British business units (Whitley, 1999), such as a low level of commitment and cooperation between firms, between employers and employees or between employees themselves, and the high level of mobility of operations. It was easy to close down the manufacturing operations due to their lack of 
integration within the subsidiary and also the low level of regulation on redundancies. The parent could cherry pick the most profitable area of the subsidiaries, which was the services side (Matten and Geppert, 2002). Only Jukka retained a manufacturing operation in the UK, which was previously part of the acquired German company and specialized in heavy duty escalators for large domestic public investors operating a 'Buy British' policy. Responses of management in the British subsidiaries reflected the characteristics outlined above.

The low level of regulation in the UK meant the closure of manufacturing operations in Amy and Karl-Heinz, mentioned earlier as part of the internationalization process, went very smoothly. In the view of the HR Director Amy UK, the UK 'is probably the easiest country in Europe to do different kinds of things [laying off personnel]. We really didn't have many obstacles.' The unilateral approach to restructuring, characteristic of Anglo-Saxon management systems, together with the weak collective employee rights in the UK, also facilitated a rapid restructuring process. There was little support from the actors within the UK NBS for a continuation of manufacturing operations in the UK. The national and occupational socialisation of local management towards finance and service priorities and the weak position of the trade unions meant the option of forming an alliance to resist the elimination of manufacturing was not available. Nor did management have the power resources to argue the case for retention since the performance of the UK subsidiaries was poor compared to other units in the MNC. Compared to the German subsidiaries, where management negotiated restructuring and outsourcing policies to maintain manufacturing and engineering competences, in the cases of Amy and Karl-Heinz the decision to close all manufacturing units in the UK was understood by the local managers as the only possible strategy to meet increasing HQ demands to improve economic performance. At Amy this process included the layoff of all manufacturing staff, the closure of the sites and the setup of a centralized customer care center at a different location where they hired new, less qualified and cheaper staff. As a result, the number of staff was about $50 \%$ of what it was before the reorganization. Karl-Heinz opted for a model with decentralized regional service centers and tried to retain the old staff while the layoff of $10 \%$ of the workforces was seen as inevitable. In both cases, however, management stressed in our interview that their reorganization measures were the only rational answers to cheaper and more efficient manufacturing locations in Eastern Europe or Asia within their respective multinational groups.

German host country rationalities. The earlier outline of German home country rationalities showed, in contrast to the UK rationalities, a general pro manufacturing ethos with a strong $R \& D$ focus, which is reflected in the education and training system and the values of local management. There is legislative support for works council rights, which gives subsidiary level worker representatives the right to influence company restructuring and can lead to an alliance of works council and local management against parent company plans. All these factors provide a strong support base for the German subsidiaries, which are not simply manufacturing units but are involved in networks of influence in the MNCs due to their R\&D strengths. A further historical and geographical factor associated with the influence of the German subsidiaries is their expertise in Eastern European markets. These were the main reasons why the MNCs had selected Germany as their key manufacturing and R\&D location. An additional factor supporting their greater strategic role and power resources is their strong performance compared to the UK manufacturing subsidiaries. German management representatives were aware of the competitive advantages of the high level of functional integration of manufacturing, engineering, $R \& D$ and services in their operations, which led to high levels of productivity in DQP. These factors had also given them high levels of autonomy within the MNC and they were keen to control these scarce resources in the future: 


\begin{abstract}
'Basically, we want to have steering systems, which we control ourselves. If we were to no longer produce them ourselves, we would lose some of our skills and initiative in this area ...firstly, these are our specialist skills in the Lifts and also the Escalators sector; secondly, we also want to retain know-how in-house; that is one of our strategies.' [Management representative in Amy Germany]
\end{abstract}

In Jukka, German managers also stressed the strong engineering and research and development traditions associated with the former German company taken over by Jukka, which had led to manufacturing being focused in Germany rather than in the US. This had required the German managers to fight their corner hard in a power struggle between the US and German manufacturing units and the parent. The parent company has, however, an ambivalent attitude towards German engineering traditions and their orientation towards DQP. Although Jukka had acquired the German specialist escalator manufacturer to learn their engineering and R\&D skills, they faced local resistance to their implementation of the standardised Jukka model with its quality standard escalator. German management and workforce fear the loss of their own national competitive advantages if they are absorbed into the global integration strategy of the parent. This illustrates some of the problems faced by MNCs when they seek to integrate subsidiaries, which are oriented towards a strong NBS and are confident of their own competitive advantages. Jukka is confronted with a works community focused on high level engineering skills, both in the German subsidiary and, to a lesser extent (due to the lower level of leverage for resistance in the more liberal British NBS), in their British subsidiary, previously part of the acquired German company. Despite the parent company's use of its power resources in the form of a team of Finnish HQ managers sent to occupy key management posts in the subsidiary, resistance is continuing. The works council and middle management are seeking to thwart the full implementation of the Jukka model by using the works council's legal rights in the area of wages, control procedures and work organisation. Management respondents were vociferous in their complaints about the possibilities of the works council to block and influence the implementation of particular elements of the Jukka model. Thus, for example, the implementation of a new wage system, which would increase the management's control of individual productivity, was opposed by the works council by reference to the Bundesdatenschutzgesetz. (Federal Data Protection Law), which prevents the abuse of personal data. Another area of resistance was to any changes in working hours without the works council's consent. The German NBS thus furnishes the local actors with power resources they can use to resist HQ plans (see also Ferner, 2000, p.537).

A further obstacle to the parental strategy is the tight integration of German manufacturing units. Amy's HR Director argued that purely manufacturing plants can be moved quite easily but not manufacturing plants tightly linked to engineering centres. This fact gives Amy's German management confidence that their role will continue to be important for the MNC. In Jukka's case we can see the complex use of control instruments to integrate their subsidiariesformal controls in the Jukka model and personal control via the Finnish 'Jukkaites'. As yet, there is limited social control due to the lack of acculturation of local management and employees into corporate culture. The fact that the German subsidiary is a relatively recent acquisition ( 5 years), that it is a high performer in a field where the parent has limited experience and that it is strategically important to the company means that the Finnish HQ will need to be careful in its forced acculturation process lest it loses those very advantages it sought in the first place in the purchase of the German company. 
In Karl-Heinz, in contrast, we found a far less conflictual restructuring process in the German lift manufacturing plant. This can be linked to the fact that both the parent and the plant belong to the same NBS and share a similar focus on DQP so there was no threat to what the plant saw as its competitive advantages - the rationalities were similar in both. In line with the German NBS, the process of restructuring was a negotiated one throughout, both in the design and implementation stages. This contrasts with the attempt in Jukka to impose changes unilaterally - the German subsidiary had not been involved in prior negotiation. Although the introduction of lean production in Karl-Heinz was a painful process, as it meant the abolition of existing workplace hierarchies, it has been successful and the plant's future is now secured within the MNC. These findings support Streeck's contention that a negotiated form of lean production is being introduced into Germany as a result of German institutional constraints, which prevent a unilateral management determined process of change (Streeck, 1996).

Our empirical research has found evidence of the significance of host country rationalities in both the British and German subsidiaries. In the British subsidiaries, there is a radical shift to a pure service orientation, which reflects priorities of the NBS. The power resources at the disposal of British management are more limited than in Germany but they use those they still have to shape the development towards a service organisation, hoping thereby to also influence the parent company in this field. The level of resistance to MNC globalization policies has been low if not non-existent. Jukkas's subsidiary is still strongly influenced by its links to the former German parent and operates in a still lucrative niche market in the UK. Up to now the Finnish parent is happy to continue its manufacturing role on this basis. The German subsidiaries in the three MNCs are still the leading manufacturing and R\&D units. This, together with their high performance levels and the added leverage from the German NBS, gives them a wider range of power resources, which they are keen to exploit, and they have a higher level of autonomy and wider range for strategic choice across the range of business functions than the British subsidiaries. Resistance to globalization strategies of the MNCs has been greatest in Jukka as it seeks to impose a global standardized rationality on a DQP-based, very German subsidiary. Any attempts by Amy to move in this direction would also meet with resistance. On the other hand, conflict is likely to be limited in Karl-Heinz. since the parent pursues a global strategy based on the advantages of the German NBS.

\section{CONCLUSIONS:}

\section{THE INFLUENCE OF DIFFERENT CONTEXTUAL RATIONALITIES ON SUBSIDIARY CHOICE IN MNCS}

Our Analysis has surfaced a rather multifaceted picture of global, home country and host country rationalities affecting managerial choice in subsidiaries of MNCs. Table 3 provides an overview over the basic findings of our case studies. All in all, our research leads us to four final conclusions. 
First, globalization strategies of a MNC are significantly shaped by the country of origin of the MNC. Internationalization or globalization in our sample has its manifestation in the development of standardized products and services for a global mass market. Consequently, Amy as the US MNC is the leader in its field. It is, however, still strongly influenced by the conglomerate to which it belongs, which is solidly rooted in the US market and seeks to communicate the dominant US model of operations. The Finnish MNC, Jukka, is in a transitional stage as it moves from being merely a Finnish champion within its own NBS to become a global player with a global manufacturing and organizational strategy. This strategy shows some similarities with a US model, particularly in its financial controls, but in other areas it is innovative and distinctive within the sector. Karl-Heinz, the German MNC, remains committed to DQP and is successful in the upper market segments of the industry branch under investigation. Its decentralized operating strategy is seen as promoting a DQP approach and precludes a standardized global manufacturing strategy.

Second, we have shown that the overall (global) management strategy of the MNC group influences decision making in host country subsidiaries by helping to shape local managers' decision-making power and resource dependencies. MNC subsidiaries have a 'bounded autonomy' (Child, 1997, p.53), which is influenced by the extent to which the parent company applies more centralized and standardized change management approaches requiring standardization of products and services. Such strategies remove critical resources from the control of the subsidiaries to HQ level (manufacturing strategy, work organization, information systems etc.) and lead to increased resource dependencies in their subsidiaries. In our case studies, this strategy has been pursued by Jukka where the subsequent reduction of subsidiary choice has led to high level of conflict. More decentralized decision-making approaches, however, allow subsidiary driven 'charter enhancements' (Birkinshaw, 2000) as demonstrated in Karl-Heinz, where the German subsidiary has adapted to new manufacturing systems in the 'German way' whilst its British subsidiary is experimenting with decentralized service centres.

Third, the subsidiary choices to maintain (in the German cases) or decrease (in the British cases) their charter responsibilities are strongly influenced by the social embeddedness in the NBS of host country subsidiaries. Most notably, they cannot just be explained with regard to 'head office assignments' and task environment settings as suggested by Birkinshaw (2000), but it is especially the NBS which provides specific power resources to subsidiaries (see Ferner, 2000). In Table 3 this can be clearly traced when comparing the British and German parts within the same column: The same global rationalities within one MNC do by no means lead to the same manifestation on the subsidiary level. Actors in subsidiaries embedded in a more socially integrated national context, such as the German, have more strategic choice in terms of retaining wide charter responsibilities, more control over their business activities and are less resource dependent. Such contexts, however, do pose disadvantages for companies seeking to enforce a rationalization strategy based on standardized products for the global market, as seen in the case studies, where the different host country rationalities of the subsidiaries can lead to conflict.

Finally, our study has surfaced significant clashes of global home country rationalities and host country rationalities particularly on the German side of the analyzed companies. In this context, Streeck has underlined the beneficial constraints of the German NBS, which prevents the erosion of trust and a low road competitive strategy, which undervalues worker involvement and skills (Streeck, 1997, p.206). Our study has shown the operation of these constraints in the general resistance of the German manufacturing subsidiaries to short- 
termism and rational accounting in their bid to secure a long-term strategy of DQP. Commentators see this as a more attractive model for future manufacturing in view of the higher level of industrialization and the growing importance of skills (Wever, 1995, p.125; Whitley, 2001, p.8). However, this social construction of contextual rationality is coming under pressure from global rationalities based on quality standard production as shown in our case studies. The challenge for MNCs will be how to respond to short-term global pressures in such a way as to retain the long-term competitive advantages of integrated engineering, $\mathrm{R} \& \mathrm{D}$ and manufacturing operations.

The last point might however allow some speculation about the chances of the German NBS to 'survive' these clashes with more anglo-saxonized global rationalities. Our data suggests a differentiated picture: Though there are certain tendencies within Karl-Heinz to adapt, for instance, to global capital markets, its - successful - internationalisation strategy is strongly characterized by home country rationalities. If we look at the degree of multinationality or the number of overseas manufacturing locations (Table 1) one could not argue that the German MNC is therefore facing significant obstacles. The same mixed picture also applies to the German NBS as a host environment for MNCs: While Germany might well pose certain obstacles to global strategies, all three MNCs deliberately 'use' the German NBS as an important element in their 'portfolio' of subsidiaries, making use of the specific strengths and opportunities of being embedded in these contextual rationalities.

Our study illustrates the continuing importance of the social construction of contextual rationalities, both at MNC HQ and subsidiary levels. Whilst global economic imperatives are critical, the ways in which MNCs and subsidiaries respond to them are varied, even within the same industry dominated by just four global players. We agree with Ferner's arguments (2000) that the investigation of the political processes within MNCs is crucial to understanding their operation and have underlined some of the key rationalities involved in the interaction between MNC HQ and subsidiary management.

*) Earlier versions of this paper have been presented at the $17^{\text {th }}$ EGOS Colloquium in Lyon, France, Subgroup 28, in July 2001 and at the ESRI Thematic Research Workshop on Changing Contextual Constructions of Economic Rationality in Portoroz, Slovenia, in September 2001. In addition to helpful advice from the audiences, the authors like to thank Anthony Ferner, Christel Lane and the two guest editors of this issue for their comments on earlier drafts of this paper. 


\section{REFERENCES}

Bartlett, C. and Ghoshal, S. (1989). Managing across borders: The transnational solution. Boston: Harvard Business School Press.

Bartlett, C. and Ghoshal, S. (1997). 'The transnational organization'. In Pugh, D. S. (Ed) Organization theory: selected readings. London: Penguin, 64-82.

Belanger, J., Berggren, C. Björkman, T. and Köhler, C. (1999). Being local worldwide: ABB and the challenge of global management. Cornell University Press: Ithaca.

Becker-Ritterspach, F., Lange, K. and Lohr, K. (2003). 'Convergence or divergence of European co-ordination and control forms in MNC's?' In Geppert, M., Matten, D. and Williams, K. (Eds), Challenges for European management in a global context. Basingstoke: Palgrave, in print.

Berger, S., Dore, R., (eds), (1996), National Diversity and Global Capitalism, Cornell University Press, Ithaca, New York.

Birkinshaw, J. (2000). Entrepreneurship in the global firm. Sage: London.

Birkinshaw, J. and Fry, N. (1998). Subsidiary initiatives to develop new markets. Sloan Management Review, 39, 51-61.

Birkinshaw, J. and Hood, N. (1998). 'Multinational subsidiary evolution: Capability and charter change in foreign-owned subsidiary companies'. Academy of Management Review, 23, 773-795.

Child, J. (1997). 'Strategic choice in the analysis of action structure, organizations and environment: retrospect and prospect'. Organization Studies, 18, 43-76.

Child, J., Faulkner D. and Pitkethly, R. (2001). The management of international acquisitions. Oxford: Oxford University Press.

DiMaggio, P. J. and Powell, W. W. (1991). 'The iron cage revisited: Institutional isomorphism and collective rationality'. In Powell, W. W. and DiMaggio, P.J. (Eds), The new institutionalism in organizational analysis. Chicago: University of Chicago Press: 63-82.

Djelic, M-L, Quack, S., (2002), From National Configurations to Transnational Recombination, Paper presented to the EGOS Colloquium, Barcelona, July.

Doremus, P.N., Keller, W.W., Pauly, L.W. and Reich, S. (1998). The myth of the global corporation. Princeton, NJ: Princeton University Press.

Ebster-Grosz, D. and Pugh, D. (1996), Anglo-German Business Collaboration: Pitfalls and Potentials. Basingstoke: MacMillan.

Edwards, T. and Ferner, A. (2001). 'Structure, politics and the management of the employment relationships in MNCs: the influence of Wall Street on employment relations in US MNCs'. Paper presented at the AGF Research Conference 'Management of change in multinational companies: global challenges and national effects. Berlin November 2001.

Ferner, A., (2000). 'The underpinnings of bureaucratic control systems: HRM in European multinationals'. Journal of Management Studies, 37, 521-538.

Ferner, A., Quintanilla, J. and Varul, M.Z. (2000). 'Country of Origin Effects, Host Country Effects and the Management of Human Resources in Multinationals: German Companies in Britain and Spain'. Journal of World Business, 36, 107-127.

Ferner, A. and Varul, M. (2000). "Vanguard' subsidiaries and the diffusion of new practices: a case study of German multinationals'. British Journal of Industrial Relations, 38, $115-140$.

Geppert, M. (2002). 'Sensemaking and politics in multinational companies: a comparative analysis of vocabularies within the global manufacturing discourse'. Paper presented at the 18th EGOS Colloquium. Barcelona July 2002. 
Girndt, C. and Meiners, K. (2002) 'Ein Manager ist nicht nur für das Kapital da', Die Mitbestimmung, No. 5, 11-15.

Hall, P.A., Soskice, D., (eds), (2001), Varieties of Capitalism-the Institutional Foundations of Comparative Advantage, Oxford: Oxford University Press

Hayden, A., Edwards, T., (2001). 'The Erosion of Country of Origin Effect: a Case Study of a Swedish MNC'. Relations Industrielles, 56, 116-140.

Hirsch-Kreinsen, H. (1998). 'Shareholder Value: Unternehmensstrategien und neue Strukturen des Kapitalmarktes'. In Hirsch-Kreinsen, H. and Wolf, H. (Eds), Arbeit, Gesellschaft, Kritik: Orientierungen wider den Zeitgeist. Berlin: Edtion Sigma.

Hunt, B. (2000). The new battleground for capitalism. Financial Times, Mastering Management Supplement, $9^{\text {th }}$ October 2000.

Iwer, F. (2000). Innovationstrends in der Aufzugsindustrie und Folgen für die Beschäftigungssituation. Projektabschlußbericht. Stuttgart: IG-Metall.

Jurgens, U., Naumann, K., Rupp, J., (2000), Shareholder value in an adverse environment: the German case, in Economy and Society, Vol. 29, no. 1, Feb., p.54-79.

Kristensen, P.H., Lilja, K., Tainio, R., (1996), Comparing Typical Firms in Denmark and Finland', in Whitley, R., Kristensen, P.H., (eds), The Changing European Firm, Routledge, London, p.113-117.

Kristensen, P.H., Zeitlin, J., (2001), The making of a global firm:Local pathways to Multinational Enterprise in Morgan, G., Kristensen, P. H. and Whitley, R. (Eds), The Multinational Firm. Oxford: Oxford University Press, p.172-195.

Lane, C. (1989). Management and labour in Europe. The industrial enterprise in Germany, Britain and France. Aldershot: Edward Elgar.

Lane, C. (1992). 'European business systems: Britain and Germany compared'. In Whitley, R. (Ed) European business systems. London: Sage, 64-97.

Lane, C. (2001). 'The emergence of German transnational companies: a theoretical analysis and empirical study of the globalization process'. In Morgan, G., Kristensen, P. H. and Whitley, R. (Eds), The multinational firm. Oxford: Oxford University Press, 69-96.

Lemola, T. and Lovio, R., (1988), 'Possibilities for a Small Country in High Tech Production-the Electronics Industry in Finland'. In Freeman, C. and Lundvall, B-A., (Eds), Small Countries Facing the Technological Revolution. London: Pinter, 139155.

Lilja, K., Räsänen, K. and Tainio, R. (1992). 'A dominant business recipe: the forest sector in Finland'. In Whitley, R. (Ed) European business systems. London: Sage, 137-54.

Lilja, K., Tainio, R., (1996), The nature of the typical Finnish firm, in Whitley, R., Kristensen, P.H., The Changing European Firm, Routledge, London, p.159-191.

Marceau, J., (1992). 'Small country business systems: Australia, Denmark and Finland compared'. In Whitley, R. (ed), European Business Systems. London: Sage, 155-175.

Marschan, R. (1996). New structural forms and inter-unit communication in multinationals. Doctoral Dissertation, A-110. Helsinki: Helsinki School of Economics and Business Administration.

Matten, D. and Geppert, M. (2002). 'Institutional Foundations of Manufacturing Strategies in Multinational Corporations: evidence from Britain and Germany'. Paper presented at the 18th EGOS Colloquium. Barcelona July 2002.

Maurice, M. (2000). 'The paradoxes of societal analysis. a review of the past and prospects for the future'. In Maurice, M. and Sorge, A. (Eds), Embedding Organizations. Amsterdam: John Benjamins, 13-36.

Moen, E. and Lilja, K. (2001). 'Constructing global corporations: contrasting national legacies in the nordic forest industry'. In Morgan, G., Kristensen, P. H. and Whitley, R. (Eds), The multinational firm. Oxford: Oxford University Press, 97-121. 
Morgan, G. (2001). 'The multinational firm: organizing across institutional and national divides'. In Morgan, G., Kristensen, P. H. and Whitley, R. (Eds), The multinational firm. Oxford: Oxford University Press, 1-24.

Mueller, F. (1994). 'Societal effect, organizational effect, and globalization'. Organization Studies, 15, 407-28.

Nohria, N. and Ghoshal, S. (1997). The differentiated network: Organizing multinational corporations for value creation. San Francisco: Jossey-Bass.

Ohmae, K. (1990). The borderless world: power and strategy in the interlinked economy. New York: Free Press.

Parker, B. (1998). Globalization and business practice: Managing across boundaries. London: Sage.

Pugh, D.S. and Hickson, D.J. (1997). 'Organizational convergence'. In Sorge, A. and Warner, M. (Eds), The IEBM handbook of organizational behaviour. London: International Thomson Business Press, 187-92.

Royle, T. (1995). 'Corporate versus Societal Culture: a comparative Study of McDonald's in Europe'. International Journal of Contemporary Hospitality Management, 7, 52-56.

Schmidt, G. and Williams, K. (2003). 'Globalisation - the 'German Model' of industrial relations on trial'. In Geppert, M., Matten, D. and Williams, K. (Eds), Challenges for European management in a global context. Basingstoke: Palgrave, in print.

Sorge, A. (1991). 'Strategic fit and societal effect: interpreting cross-national comparisons of technology, organization and human resources'. Organization Studies, 12, 161-90.

Sorge, A. (1993). Arbeit, Organisation und Arbeitsbeziehungen in Ostdeutschland (Antrittsvorlesung 24. Mai 1993). Berlin: Humboldt-Universität.

Sorge, A. (2000). 'The diabolical dialectics of societal effects'. In Maurice, M. and Sorge, A. (Eds), Embedding organizations: societal analysis of actors, organizations, and socio-economic content. Amsterdam: John Benjamins, 37-56.

Streeck, W., (1996), Lean production in the German automobile industry, in Berger, S. Dore, R. (eds), National Diversity and Global Capitalism, Cornell University Press, Ithaca, New York, p.138-170.

Streeck, W. (1997). 'Beneficial constraints:on the economic limits of rational voluntarism'. In Hollingsworth, J. R. and Boyer, R. (Eds), Contemporary capitalism: the embeddedness of institutions. Cambridge: Cambridge University Press, 197-219.

Tainio, R., Huolman, M. and Pulkkinen, M. (2001). 'The internationalization of capital markets: how international institutional investors are restructuring Finnish companies'. In Morgan, G., Kristensen, P. H. and Whitley, R. (Eds), The multinational firm. Oxford: Oxford University Press, 153-71.

Vitols, S., (2001), Varieties of corporate governance: comparing Germany and the UK, in Hall, P.A., Soskice, D., (eds), (2001), Varieties of Capitalism-the Institutional Foundations of Comparative Advantage, Oxford: Oxford University Press, p.337-360.

Weick, K.E. (1979). The social psychology of organizing. New York: McGraw-Hill.

Wever, K.S. (1995), Negotiating Competitiveness-Employment Relations and Organizational Innovation in Germany and The United States, Boston, Massachusetts, Harvard Business School Press.

Whitley, R. (Ed) (1992). European Business Systems, London: Sage

Whitley, R. (1996). 'The social construction of economic actors: institutions and types of firms in Europe and other market economies. In Whitley, R. and Kristensen, P. H. (Eds), The changing European firm. Routledge: London: 39-66.

Whitley, R. and Kristensen, P. H. (Eds) (1996), The changing European firm. Routledge: London 
Whitley, R. (1997). 'Business systems'. In Sorge, A. and Warner, M. (Eds), The IEBM handbook of organizational behaviour. London: International Thomson Business Press, 173-86.

Whitley, R. (1999). Divergent capitalisms. The social structuring and change of business systems, Oxford: Oxford University Press.

Whitley, R. (2001). 'Authority sharing, careers and competence development in different market economies'. Paper presented at the 17th EGOS Colloquium. Lyon July 2001.

Whittington, R. and Mayer, M. (2000). The European corporation: strategy, structure, and social science. Oxford: Oxford University Press.

Wood, S. (2001), Business, government and the patterns of labour market policy in Britain and the FRG, in Hall, P.A., Soskice, D., (eds), Varieties of Capitalism-the Institutional Foundations of Comparative Advantage, Oxford: Oxford University Press, p.247-274. 
Table 1: $\quad$ Basic data about the companies studied

\begin{tabular}{|c|c|c|c|}
\hline & $\begin{array}{l}\text { MNC } \\
\text { "Amy" }\end{array}$ & $\begin{array}{c}\text { MNC } \\
\text { "Jukka" }\end{array}$ & $\begin{array}{c}\text { MNC } \\
\text { "Karl-Heinz" }\end{array}$ \\
\hline Country of origin & United States & Finland & Germany \\
\hline Total number of employees worldwide & 63,000 & 23,000 & 28,500 \\
\hline $\begin{array}{l}\text { Multinationality index } \\
\text { - } \quad \text { proportion of employees abroad } \\
\text { - } \text { proportion of sales abroad }\end{array}$ & $\begin{array}{l}\text { - } \quad 84 \% \\
\text { - } \quad 76 \%\end{array}$ & $\begin{array}{l}\text { - } \quad 94 \% \\
\text { - } \quad 91 \%\end{array}$ & $\begin{array}{l}-\quad 93 \% \\
-\quad 89 \%\end{array}$ \\
\hline No. of countries with overseas subsidiaries & 200 & 40 & 102 \\
\hline No. of overseas manufacturing plants & 39 & 14 & 23 \\
\hline $\begin{array}{l}\text { Size of German subsidiary: } \\
\text { - } \quad \text { sales (in Million Euro) } \\
\text { - } \quad \text { employees }\end{array}$ & $\begin{array}{ll}\text { - } & 700 \\
\text { - } & 4000\end{array}$ & $\begin{array}{ll}\text { - } & 243 \\
\text { - } & 1800\end{array}$ & $\begin{array}{ll}\text { - } & 421 \\
\text { - } & 1822\end{array}$ \\
\hline $\begin{array}{l}\text { Size of UK subsidiary } \\
\text { - } \quad \text { Sales (in Million Euro) } \\
\text { - Employees }\end{array}$ & $\begin{array}{ll}\text { - } & 144 \\
\text { - } & 2700\end{array}$ & $\begin{array}{ll}\text { - } & 205 \\
\text { - } & 1295\end{array}$ & $\begin{array}{l}-\quad 120 \\
-\quad 800\end{array}$ \\
\hline
\end{tabular}

Sources: Annual Reports 2001 and interviews by the authors 
Table 2: Interviews conducted in the companies

\begin{tabular}{|l|c|c|c|c|}
\hline & $\begin{array}{c}\text { MNC } \\
\text { "Amy" }\end{array}$ & $\begin{array}{c}\text { MNC } \\
\text { "Jukka" }\end{array}$ & $\begin{array}{c}\text { MNC } \\
\text { "Karl-Heinz" }\end{array}$ & Total \\
\hline At HQ interviews conducted & 1 & 2 & 2 & 5 \\
\hline In German subsidiary & 4 & 4 & 5 & 13 \\
\hline In UK subsidiary & 3 & 3 & 4 & 10 \\
\hline Total & 8 & 9 & 11 & 28 \\
\hline
\end{tabular}




\section{Table 3: The impact of global, home country and host country rationalities on multinational corporations}

\begin{tabular}{|c|c|c|c|}
\hline & MNC "Amy" & MNC “Jukka” & MNC “Karl-Heinz" \\
\hline $\begin{array}{l}\text { Global } \\
\text { rationalities }\end{array}$ & $\begin{array}{l}\text { - Long standing financial } \\
\text { market oriented group wide } \\
\text { controlling systems and } \\
\text { processes } \\
\text { - Rationalization of global } \\
\text { manufacturing } \\
\text { - Worldwide implementation of } \\
\text { ethical codes } \\
\end{array}$ & $\begin{array}{l}\text { - Increasing implementation of } \\
\text { finance driven group wide } \\
\text { controlling systems and } \\
\text { processes } \\
\text { - Standardization and } \\
\text { convergence of structure and } \\
\text { processes globally (“Jukka } \\
\text { model”) }\end{array}$ & $\begin{array}{l}\text { - Opening towards } \\
\text { international financial } \\
\text { markets (reporting in US- } \\
\text { GAAP); "diluted } \\
\text { shareholder value" } \\
\text { philosophy }\end{array}$ \\
\hline $\begin{array}{l}\text { Home } \\
\text { country } \\
\text { rationalities }\end{array}$ & $\begin{array}{l}\text { - "Wall Street" driven: focus on } \\
\text { short term financial } \\
\text { performance } \\
\text { - dislike for worker' } \\
\text { representatives } \\
\text { - US-home market focus }\end{array}$ & $\begin{array}{l}\text { - Transition from "patient } \\
\text { capital" towards more stock } \\
\text { market driven short term } \\
\text { performance oriented } \\
\text { investments } \\
\text { - Gradual process of opening } \\
\text { for international investors } \\
\text { - Consensus still an important } \\
\text { value } \\
\text { - Technology focus } \\
\text { - Governance implemented } \\
\text { through Finnish nationals } \\
\text { ("Finnish Mafia") }\end{array}$ & $\begin{array}{l}\text { - Decentralized } \\
\text { conglomerate } \\
\text { - Engineering centered } \\
\text { - Diversified quality } \\
\text { production } \\
\text { - Strong influence of } \\
\text { worker's representation }\end{array}$ \\
\hline $\begin{array}{l}\text { Host country } \\
\text { rationalities: } \\
\text { Britain }\end{array}$ & \multicolumn{3}{|c|}{$\begin{array}{l}\text { - Education and training system: low importance of manufacturing and engineering } \\
\text { - National customer requirements: Anglo-Saxon service culture; "Buy British" philosophy of } \\
\text { large domestic public investors } \\
\text { - Labour market: high flexibility } \\
\text { - National specifications of the lifts- and escalator industry }\end{array}$} \\
\hline & $\begin{array}{l}\text { - Closure of manufacturing } \\
\text { - Sales \& Service only } \\
\text { organization }\end{array}$ & $\begin{array}{l}\text { - Manufacturing of small batch } \\
\text { units, highly specialized } \\
\text { crafts production }\end{array}$ & $\begin{array}{l}\text { - Closure of manufacturing } \\
\text { - Sales \& Service only } \\
\text { organization }\end{array}$ \\
\hline \multirow[t]{2}{*}{$\begin{array}{l}\text { Host country } \\
\text { rationalities: } \\
\text { Germany }\end{array}$} & \multicolumn{3}{|c|}{$\begin{array}{l}\text { - Education and training system: strong manufacturing and engineering culture } \\
\text { - High esteem for R\&D and new technologies } \\
\text { - } \quad \text { Labour market: strong influence of works councils } \\
\text { - National engineering control system of the lifts- and escalator industry: TÜV }\end{array}$} \\
\hline & $\begin{array}{l}\text { - Germany as key R\&D and } \\
\text { manufacturing location for the } \\
\text { global group }\end{array}$ & $\begin{array}{l}\text { - Germany as important R\&D } \\
\text { and manufacturing location } \\
\text { for the global group } \\
\text { - Strong and persistent } \\
\text { opposition to implementing } \\
\text { global convergence }\end{array}$ & $\begin{array}{l}\text { - Subsidiary is a typical } \\
\text { German SME } \\
\text { ("Mittelstand") } \\
\text { - Leadership in R\&D and } \\
\text { engineering tasks within } \\
\text { the MNC }\end{array}$ \\
\hline
\end{tabular}

